\section{Productivity, public capital, and socialism with Chinese characteristics - A critique of the doctrine of incompatibility between capital and public ownership}

Productivity, public capital and socialism

\author{
Zhaozi Rong
}

Institute for Advanced Study of Economic and Social Development, Anhui University, Hefei, China

\begin{abstract}
Purpose - This paper is a response to the doctrine that capital is incompatible with public ownership. The fundamental characteristics of modern productivity determine the co-existence of the market economy and capital relations.

Design/methodology/approach - Socialism can neither bypass the market economy nor "go beyond capital"; capital appears in two historical forms, including the private capital and the public capital. Public capital is the inevitable outcome of the inherent contradictions of public ownership in a socialist market economy.

Findings - It represents an economic relationship that compels individual labourers to provide surplus labour for the society. The combination of the strong accumulation function of public capital and the improvement of people's welfare is the main cause of China's development miracle.

Originality/value - The innovation impetus of the public capital and its "immunity" to the capitalist crisis highlight the tremendous power of socialism with Chinese characteristics in breaking free of the shackles of capitalism and continuously developing productive forces. Public capital demonstrates and will continue to demonstrate the historical legitimacy of socialism.
\end{abstract}

Keywords Modern productivity, Public ownership of capital, Public capital, Socialism with Chinese characteristics

Paper type Research paper

Over the past 30 years, the reform of China's state-owned economy has always followed the logic of the public capital. While the ownership of the means of production remains unchanged and state-owned capital belongs to the whole people, large- and medium-sized state-owned enterprises (SOEs) are transformed into the form of a corporation. After that, the two-way selection mechanism has taken initial shape in the labour market, and a relationship of the market transaction between labourers and owners of state-owned capital has formed. The reform of the state-owned economy is continuing according to this logic, and the focus of

\section{JEL Classification - B24, P26, P51}

(C) Economic Research Journal. Published in China Political Economy. Published by Emerald Publishing Limited. This article is published under the Creative Commons Attribution (CC BY 4.0) licence. Anyone may reproduce, distribute, translate and create derivative works of this article (for both commercial and non-commercial purposes), subject to full attribution to the original publication and authors. The full terms of this licence may be seen at http://creativecommons.org/licences/by/4.0/ legalcode. Originally published in Simplified Chinese in Economic Research Journal.
Received 25 May 2020

Revised 15 June 2020 Accepted 15 June 2020 
CPE 3,1

the management system of the state-owned economy will shift from managing enterprises to managing capital. Two views constantly challenge this reform orientation: Some criticize that this reform is incomplete and that corporations should seek privatization. They believe that public ownership as the main does not meet the requirements of the market economy's logic and is an ideological redundancy. Others argue that the capital's logic is contrary to the nature of socialism and that the public capital is a kind of "capitalism without capitalists" (Amin, 2003) or that capitalism will come back sooner or later (Mèszaros, 2003) [1]. These views are derived from the same doctrine that capital is incompatible with public ownership. This paper intends to make a response to the above misunderstandings with the following points: first, the market economy and capital relations are historical characteristics that socialism cannot bypass. Second, capital can be privately owned or publicly owned. Third, a market economy dominated by the public capital is the primary driver of China's growth miracle. Public capital is the fundamental guarantee for socialism with Chinese characteristics to break free of the shackles of capitalism and continuously develop social productivity.

\section{The common foundation of productivity of market and capital}

There used to be many different interpretations regarding why SOEs adopt the reform with the direction of capital- oriented ownership. The comparative institutional theory and institutional economics have similar analysis paths, mostly starting from comparing the productivity of enterprises under capital-oriented ownership and those under labour-oriented ownership in the case of market economy and drawing a conclusion that the former is more productive than the latter. As this conclusion matches the facts about ownership of enterprises in most countries in the market economy, it is somewhat tenable. However, such an explanation is limited to the level of phenomena as it neither discusses the essential requirements of the market economy and the historical nature of capital relations nor discusses and compares the connection and relationship of the market economy as well as capital relations with social productivity. Therefore, it cannot further explain the in-depth historical reasons for the higher efficiency of enterprises under capital-oriented ownership in a market economy, which is the very perspective of Marxist historical materialism.

During the creation of the book Capital (especially the manuscripts in 1857-1858), Karl Marx discusses in depth the conditions of productive forces for the evolution of "value relationship and value-based production" in the future. Marx carries out the analysis from three interrelated angles, as follows: (1) The wealth criterion evolves from the labour time to free time and the all-round development of individuals. With the rapid development of social productivity, "there is an astonishing disproportion between the labour time spent and the products of labour" (Marx and Engels, 1980), and the amount of labour invested in direct production has an increasingly less effect on wealth. With the reduction of workdays and the increase of free time, people's all-round abilities are more used for free creative activities, and general productive forces based on personal capacities (e.g., science and technology and their application in production) develop more rapidly. The opposition between the necessary and surplus labour disappears gradually (Marx and Engels, 1980). Free time is not only the surplus time for individuals apart from labour but also a driver of the development of productive forces for a society (Marx and Engels, 1980). Labour time is no longer and cannot be a wealth criterion (Marx and Engels, 1980). The value-based production will come to an end naturally.

(2) The relationship between human beings and the production process changes fundamentally. The progress of science and technology, as well as its application in production, is reflected in the machinery system. The specific manifestation is as follows: Automated and intelligent production develops rapidly and leads to the exit of all 
programmed, repetitive work that can be done by machines instead of labourers from labourers' activities. The role of labour will shift from a "component" of the machinery system deeply integrated into the direct production process to the master supervising and controlling the production process. Marx further points out that this conclusion, which applies to the machinery system, also applies to all human communication processes (Marx and Engels, 1980). With the re-reversal of the relationship between humans and the material process, the alienation characteristic of the commodity economy - reflecting the connection of humans through the connection of objects - cannot exist.

(3) The social nature of labour changes fundamentally. A rapid progress in labour productivity promotes the evolution of the form of division, and the old division characterized by professional specialization disappears over time. The "detail-worker. . . reduced to a mere fragment of man" are placed by "the fully developed individual, fit for a mixture of labours, which are derived from the various social functions he/she is qualified for (Marx, 1975). Disgusting and cursed labours that go against human nature and result in the uneven development of individuals change into attractive free activities that are suitable for human nature and conducive to the all-round development of individuals because of the change of the ratio of the necessary labour to free activity, the social status of humans in the process of production and the form of division of labour (Marx and Engels, 1980). Individuals' subjective perception of a productive labour changes fundamentally - labour is no longer a means of livelihood for individuals or a scarce resource for a society. Therefore, the market economy with labour time as a scarcity index will end inevitably (Rong, 2000).

It is worth noting that all the three abovementioned angles of view are intrinsically closely related to capital. Capital is a social relationship, and value production is a precondition for the existence of capital relations. Although the forms of capital change continually in movement, capital is an independently proliferating value entity by nature. Therefore, without the foundation of value production, capital will become water without a source or a tree without roots. As long as the value ratio and the contradiction between the necessary labour and surplus labour still exist, the possibility of capital relations always exists.

The reversed relationship between human beings and the production process is a more critical dimension for capital. Only from this perspective can the rule of property rights over people have a substantial foundation, and the rule of capital as a creation of labour over labourers is the product of the development of the social productivity at a certain level. If human beings as the main body of activities cannot stand outside the material exchange between man and nature to supervise and regulate it, then the dominance of human beings over the process of material exchange is always untenable. Therefore, it is possible that value, which also alienates the nature of labour, may have the same historical end as capital has.

More logically convincing is the third analysis perspective. The social nature of labour is the result of a series of historical factors. On the one hand, labour determines the adverse effects on most labourers' psychological feelings, i.e., sacrifice, burden, or so-called "disutility" in modern economics. Therefore, labour is just a means of making a living for individuals, and labourers do not voluntarily provide surplus labour beyond the necessary labour that meets the needs of consumption. On the other hand, labour is also the means of production and measurement scale of social wealth. Wealth could not be accumulated without accumulation of past labour, and social production could not develop without accumulation of surplus labour. Based on the above two points, there is an apparent contradiction between labourers' interests and social interests. The scarcity of labour to a society is a concentrated expression of the above contradiction, and the extension of the labour time beyond the necessary labour time is the focus of the struggle between individuals and society. Capital is a tool used by a society to "reconcile" this contradiction and plays an irreplaceably leading role throughout the historical period during which the nature of labour remains unchanged. According to Karl Marx, “. . . the great historical contribution of capital
Productivity, public capital and socialism 
CPE 3,1

is to create surplus labour, that is, superfluous labour from the point of pure use-value and survival" (Marx and Engels, 1979). The means adopted by capital to exercise its mission is coercion, including "administrative coercion" of labourers in the enterprise and "competitive coercion" featuring survival of the fittest in the market. Capital is the executor of the two types of coercion mentioned above and is also coerced by its internal impulsion during the endless pursuit of surplus value. Just think - is there any better way to solve this historical contradiction between the individuals and society?

According to Marx, once the world develops to the following stage, it needs to develop to such a degree that the surplus labour beyond the necessary labour becomes a general need originating from individual needs and general diligence evolves into the general property of a new generation due to the strict discipline of capital for generations. Eventually, as capital's endless desire to get rich and the only condition to realise such a desire continues to drive further development of labour productivity, the preceding general diligence reaches such a degree that the whole society requires less labour time to possess and maintain general wealth and that the society will scientifically treat the process of reproduction, which is increasingly abundant. Thus, human beings no longer take up the labour that can be done by objects instead of humans, and the historic mission of capital is accomplished by that time (Marx and Engels, 1979).

Upon a review of Marx's statement on the historical conditions for surpassing capital, it is not difficult to find that those conditions highly overlap the conditions for the demise of the market economy. At least in Marx's opinion, these two events are regarded as the same historical development. Marx's argument contains three levels, as follows: First, "general diligence" and labour become a "general need". Second, "the whole society requires less labour time to possess and maintain general wealth". Third, "the society will scientifically treat its process of reproduction, and "human beings no longer take up the work that can be done by objects instead of humans". These three levels of meaning form a one-to-one correspondence to the preceding three perspectives for the demise of the market economy, which shows the rigorous logic in Marxist theoretical analysis.

\section{Productivity developments after Marx's era}

Karl Marx's conclusion about the inevitable demise of the commodity economy and capital relations is not a groundless imagination; instead, it is based on the actual development and emerging trends of a large-scale capitalist machine production. With regard to Marx's views mentioned above, almost every occasion and the characteristics of the future society are always closely related to observation results of the realistic trends of a large-scale machine production. Nevertheless, Karl Marx never confuses both issues. For Marx, the dynamics and directivity of the realistic trend and the possibility and inevitability of the future result are not the same things, and there is a massive gap of degree and time span between them. Marx firmly believes in the correctness of his prediction from the perspective of historical materialism, but he does not think that this possibility of the future will be realised soon. Marx's prediction about the time of realisation of the future society is not confirmed. Sometimes he predicts that this society will appear soon. Sometimes he makes people think that this involves a rather long development process (Gu, 2014).

Then, what has happened in more than 100 years since the decease of Karl Marx? At least the following conclusions are apparent:

\subsection{First, Marx's forecasts on productivity growth trend are correct. Therefore, his expectations of the future society are well-founded \\ The following three indicators suffice to prove the author's judgements:}


The length of the workday

In the generation of Karl Marx, the workday of British workers was generally more than $10 \mathrm{~h}$. According to many actual materials cited in Capital, workers' workday usually exceeded $12 \mathrm{~h}$. Therefore, the working hours of workers should range between $70 \mathrm{~h}$ and $80 \mathrm{~h}$ a week. Compared with it, the working day nowadays is significantly shorter as people in average countries under the market economy today work eight hours a day, five days a week, i.e., 40 working hours a week. According to Maddison's calculation (2003), in 12 European countries, including the UK and Germany, the annual work hour per capita was 1,295 h in 1870 and fell about $50 \%-657 \mathrm{~h}$ in 1998 . The figure declined slowly in the US and Japan within the same period, but the primary trend was also evident. Based on this trend, can we imagine that the working hours of workers in those countries might fall to $20 \mathrm{~h}$ per week within 150 or 200 years, that is, around the year 2,200? Is it possible that the figure may fall further to $10 \mathrm{~h}$ per week by 2,400 ?

\section{The level of production automation}

For the advanced manufacturing industry in Britain observed by Marx, the large-scale machine production just emerged. Since then, the development of production automation for more than 100 years, no matter in terms of depth or breadth, is far beyond people's imagination, and even beyond Marx's imagination. In particular, due to the development of computer and network technologies, not only physical labour but also brainwork in large quantities can be replaced by machines. In the modern production, all kinds of manipulators and robots are used more and more widely, and learning robots, such as "Deep Blue" and "Deep Thought", are catching up with humans, in competitions. It fully shows the high possibility that machines will gradually replace all the monotonous and programmable human labours in the future. A sci-fi automatic material production system involving no direct human labour is coming closer to reality at a dazzling pace. It must be noted that Marx's prediction in this respect is not limited to the machine systems but also includes all human interaction activities. In other words, human beings can stand beside the automatic machine system and become the supervisor and regulator of the system, and "their social relations as their common relations" will be "subject to their common control" (Marx and Engels, 1979). Not long ago, according to the features of the centralized big machine systems, people believed that Marx's expectation of the planned economy could only be realised with a centralized social planning centre. Nowadays, the technical possibility of a distributed network system that incorporates information flow, energy flow and material flow has fully appeared, and there is every reason for us to stretch our imagination on the economic coordination mechanism in the future society. The future planned economy may be a democratically planned economy based on global network technology, with the participation of all individuals in society, highly intelligent tools, fully open big data about the economy and distributed neural networks. Such a planned economy will surely optimise the resource allocation and save the labour time more efficiently than the centralized planned economy previously contemplated. Karl Marx did not witness the development of the computer and network technologies and naturally could not imagine it in this way. Nevertheless, he gains an insight into the historical trends ingeniously through his deep understanding of the nature of productivity in the market economy.

\section{The all-round development of individuals}

Marx believes that the increasingly frequent change of labour and functional substitution in the large-scale machine production is beneficial to the improvement of workers' ability (Marx, 1975). During the global economic development history of over 100 years after Marx's era, at least two events are of obvious positive significance to the elimination of the old division of labour.
Productivity, public capital and socialism 
CPE 3,1

First, the development of general education and vocational education enables more and more labourers to receive more comprehensive, systematic knowledge and skill training. The broad academic calibre and basic courses in general education help students to gain more extensive adaptability and development potential in their employment. Vocational education providing training on relevant techniques and practices enables labourers to make a free choice among multiple jobs at the very beginning of their careers. According to Maddison's data (2008), within 1952-1998, the average length of schooling in China increased from 1.6 years to 8.5 years. However, this is not the limit. Within the same period, the average length of schooling in France rose from 9.58 years to 15.96 years, while the American figure jumped from 11.27 years to 18.04 years. Undoubtedly, it is a long-term trend that the labourers' schooling length increases with rising social productivity, and it has a lasting impact on the all-round development of labourers' qualities. Second, the requirements of modern productivity on the ability and quality of labourers are changing. The supply structure of the labour force is closely related to changes in the demand structure of the labour force. On the one hand, the proportion of white-collar labourers mainly engaged in mental work is going up year by year, and the requirement of production processes on the schooling length of labourers continually increases. On the other hand, the rapidly increasing technological content of the machine systems poses an increasingly high requirement on the comprehensive ability of operators. Gordon et al. (1982) pointed out the co-existence of "re-skilling" and "de-skilling" of workers, which is typically reflected in a higher demand of a flexible automation production for multi-skilled workers. It is certain that the requirement of the social productivity development is the root cause of the all-round improvement of workers' skills and that no institutional obstacle can change this longterm trend.

\subsection{Second, the realisation of the future society anticipated by Karl Marx requires more time for the development of global productivity}

According to the three indicators mentioned above, this point is evident. Although the length of workday decreases considerably, 40 or even 36 working hours a week are not enough to guarantee that labourers can develop their "free individuality" in an all-round way after work. Although the modern science and technology show the high probability of the production automation, it is too early to make sure that humans are no longer engaged in all labours that can be done by machines in all the material production processes. Also, it is even harder to accomplish the goal of eliminating the old division of labour. Although labourers' ability is improving gradually, the path to improving the labour productivity effectively without relying on the deepened division of labour is still unclear currently, at least for the time being.

Considering the following two points, people will be more aware of how far away the human productivity is from the turning point from quantitative change to qualitative change.

First, the productivity development is increasingly unbalanced worldwide. The above analysis of the social productivity status focusses on developed market economies. However, the demise of value production and capital relations cannot be separated from the background of economic globalization. A country or a few developed countries cannot enter into communism alone as the prosperity and wealth of modern developed countries benefit from global market competition. From this perspective, the global productivity is even farther from the ideal turning point. Taking GDP per capita of each country as an approximate indicator of the labour productivity, Maddison's calculation (2003) clearly shows the imbalanced development of the global productive forces under capitalism. By 1998, the global average GDP per capita was 5,709 international dollars, and the GDP per capita of the developed countries in Europe, the US and Japan were around 20,000 international dollars. The GDP per capita of Latin American and Eastern European countries neared the global figure; the GDP per capita of developing countries in Asia and Africa hovered around 2,000 international dollars. The maximum regional gap was 19:1. The overall gap between the 
developing countries of Asia and Africa and developed countries is generally ten times and is still widening. To make the global economy develop to the level of developed countries, or even higher than the current level of developed countries, in a more balanced state, it must be a laborious, long process, even merely from the perspective of productivity.

Second, the productivity growth must go through a fundamental change in the energy structure. The rapid development of the capitalist market economy in hundreds of years is synchronous with the large-scale utilisation of the non-renewable mineral energy resources. The faster the development of productivity, the faster the exploitation and consumption of coal and petroleum (and thus the more serious the pollution to the Earth's environment). Humans intensively utilise the solar energy accumulated by the Earth over several billions of years and develo social productivity in a supernormal way within a particular, short historical period. However, the mineral energy resources deposited will be used up over time. Human beings must get ready the technology for the effective utilisation of the new energy resources before the exhaustion of the traditional energy resources. Even so, the model of speeding up the development of productivity by accelerating the consumption of "Earth's deposits" cannot be repeated. The utilisation of renewable energy resources needs to start from the capture of solar energy instead of the release of energy resources already captured. Therefore, the acquisition of an equivalent amount of energy will take more labour or require higher productivity. Marx always maintains that the abundance of natural resources affects the labour productivity. The fundamental transformation of the energy structure is essentially one of the most severe "downgrading" of the Earth's resources due to the influence of human behaviour. This day is approaching, and it will affect the progress of global productivity. Humans cannot stride forward from the realm of necessity to the realm of freedom until it leaps over the "Kafdin Valley" of productivity.

As long as the global productive forces continue to develop, the demise of value production and capital relations is inevitable. However, the arrival of that day still takes some time as the modern market economy is a relatively long historical period during which value production and capital relations adapt to specific productivity conditions, and they always depend on each other. Therefore, the phenomenon that enterprises under capital-oriented ownership are more productive in the market economy can be explained from the perspective of historical materialism.

\section{The possibility of the public capital}

Capital relations are prevalent in the market economy, while the public capital is the inevitable outcome of inherent contradictions of public ownership in the market economy.

First, the separation of the two factors of production is doomed to be separate because of the labourers' dual roles. The subject of socialist public ownership is a collective of labourers, and labourers, regardless of the number or size, exercise their property-ownership rights via equal collective decision-making. As an owner of public property and also the owner of their own labour power, every labourer decides the use and distribution of hi/her own labour power independently. Therefore, each individual has dual identities - the shared owner of the means of production and the owner of their labour power. The interest demands of both identities are not always consistent - public interest requires the accumulation of a surplus labour, while individual interest regards labour as a sacrifice or burden. Torn between the dual identities, the labourers, as the owners of two different factors of production, play a game with themselves. They control individual behaviour through collective decisions and compel individuals to provide more surplus labour for the society through incentive systems.

Second, the public property agency system results in the difference in labourers' decisionmaking right. Like any other economic system, a public ownership involves institutional costs (or generally known as transaction costs in modern economics). The internal decisionmaking costs of a public ownership economy will increase with the expanding size of
Productivity, public capital and socialism 
CPE 3,1

property rights and a growing number of persons in the collective. In order to improve the management efficiency, labour collectives have to accept specialized supervisors and administrators, and the principal-agent system is thus inevitable. As a specialized administrator, the agent wields public rights to perform the property management and labour management functions. As an individual with exclusive rights, the agent is antagonistic to other people. Also, labour managers may loaf on the job (Alchian and Demsetz, 1994), and a bottom-up supervision mechanism is indispensable. It forms a two-way supervision mechanism, i.e., a two-way principal-agent relationship. Thus, one-to-all supervision corresponds to all-to-one supervision. Administrators enjoy a unique position in the public ownership economy and the equal relationship of decision-making changes.

Third, the growing size of the public property leads to an imbalance in the two-way agent chain. With the expanding scale of the public property, the direct agent system evolves into the more economical indirect agent system. Moreover, the democratic collegiate system featuring the participation of all members evolves into the democratic representative system and multi-layered representative conference system. The state-owned economy is the largest publicly owned organisation, where the intrinsic contradictions of public property rights appear most striking. Labourers supervise the agents through the representatives elected by them and supervise top administrators through the delegates elected by such representatives. Accordingly, the management system of public property rights evolves into a hierarchical bureaucracy. The two-way agency chain is extended gradually. "In reality, that bottom-up agency chain is fragile, which is determined by the economic law that collective monitoring weakens due to the increased size of public property. Hence, state ownership reflects a strong property right exercising top-bottom management but fails to reflect bottom-up labourers' sovereignty accordingly." (Rong, 1996)

All this provides the possibility of the public capital but does not equal reality. According to Marx, the historical premises for capital generation are as follows: material conditions of production are separate from human conditions of production, and these two production factors are combined through the trading of labour power as a commodity. How does the separation occur under the public ownership?

The last step of the transition from possibility to reality is the separation of the two labour collectives in the public economy, i.e., separation of the collective of shared owners of the property and the collective of labourers of an enterprise. State ownership of means of production is the most typical condition. State ownership cannot cover the whole national economy as agriculture and other small economies cannot be integrated into the unified "state syndicate". State ownership indicates that the whole people own all property according to law. In fact, labourers employed by SOEs are only a small fraction of all labourers. The collective of labours is included in the collective of owners of the property, but these two collectives do not coincide completely. Therefore, even under a planned economy, state ownership has the recruitment quota and implements the "eight-grade wage scale". With the development of a market economy, transactions in various economic forms are formed gradually, and the separation of the two collectives within the public ownership is increasingly prominent. Due to the reform to introduce the corporate system into the SOEs, the state-owned assets are converted into the state-owned stock rights, and enterprise assets are converted into independent corporate assets. As "masters of the country", labourers of enterprises are no longer directly combined with the means of production. Instead, they make the transaction with corporate capital under actual operation on the labour market, thus generating the buyer-seller relationship of the labour force as a commodity. The development of a mixed ownership economy makes the separation of labour from capital more reasonable.

Public capital is still a kind of capital. It is a value that can be multiplied by itself and is also a social mechanism that combines administrative coercion of departments and competitive 
coercion of the market to force labourers to provide surplus value. However, unlike private capital, public capital no longer manifests itself as a class exploitation relationship. Instead, it is reflected in the control of the will of labour collective over individuals and an economic relationship that the owners of the public capital force individual labourers to provide surplus labour for the society for free.

Socialists have gone through long-term practice before finally realizing the inevitability of a public capital.

At the beginning of the October Revolution in 1917, the Communist Party of the Soviet Union (CPSU) led by Vladimir Lenin attempted to establish a workers' nation directly managed by all workers. However, this attempt suffered setbacks in practice. The debate on "nationalization of trade unions" within CPSU in 1919-1921 highlighted a fierce collision between ideal and reality. Lenin first found this problem in practice and sent a clear signal to the whole party that it was unrealistic to build the departments of state power or even manage factories based on trade union organisations. What Lenin faced was the contradiction between labourers' interests, local interests and social interests under conditions of modern productive forces, and a severe conflict between the spontaneous behaviour of workers liberated from "the strict discipline of capital" and various pressing rigid tasks of the new state. He advocated the implementation of centralism, single-head system and delegation system in economic management for heightening labour discipline and improving management efficiency. To convince the whole Party, Lenin spent two years but finally had to take disciplinary methods to expel several wrong-headed party members from the CPSU. It was this inner-party debate that established the hierarchical structure of the socialist system of the Soviet Union for 70 years (Rong, 2010). According to the Marxist logic on the "historical mission of capital", the hierarchical system is just the administrative coercion of labourers inside the organisation. Without the complementarity of the competitive coercion in the market, the role of the hierarchical system in labour discipline, innovation incentive and resource allocation is still incomplete. Later on, Lenin advocated a market-oriented reform, aka "New Economic Policy". Unfortunately, this reform direction was reversed due to the Stalin model. It was not until after the World War II that several socialist regimes in Eastern Europe revived the reform of market socialism. Among them, market socialism with "labour autonomy" in Yugoslavia was especially eye-catching.

The outstanding characteristic of Yugoslavia's pattern is workers' autonomy plus social ownership, which has a unique significance in socialistic practice. In the name of the social ownership, the state gradually withdrew from the status of the owner of means of production. Meanwhile, the power of the grass-roots economic units marked by the workers' collective decision-making gradually expanded and became the micro-foundation of market socialism. Workers' autonomy granted workers the right to decide on significant matters like enterprise production and distribution. Labour autonomy greatly stimulated individuals' and enterprises' enthusiasm for production and created good results in the economic development. From 1954 to 1964, Yugoslavia's gross national product grew at an annual average rate of $8.6 \%$, making the country one of the world's fastest growing economies at that time (Yu et al., 2008). However, the underlying problems of this experimental system were also gradually exposed at the same time: The income distribution of enterprises tends to "eat up and allocate all" without using the revenue for accumulation. Skyrocketing salaries and inflation occurred the in macro-economy. After the middle 1960s, Yugoslavia's economic growth slowed down, and its inflation was severe. From 1969 to 1974, the actual annual inflation rate was $17 \%$, which was accompanied by rising unemployment, widening gaps on personal income and expanding wealth gap among different regions (Yu et al., 2008). The golden period of Yugoslavia's model thus ended.

Yugoslavia's model mentioned above was carried out under the market economy and thus produced the effects different from those of the Soviet Union model. Due to the external
Productivity, public capital and socialism 
CPE 3,1

pressure of market competition, labour sovereignty of enterprises did not lead to the collapse of labour discipline. Instead, it stimulated labourers' enthusiasm for production (Schweickart, 2002) [2] which was undoubtedly the positive experimental outcome of that system. However, the system failed to solve the conflict between labourers' interest, local interest and overall social interest or to shoulder the historical mission of compelling individual labourers to "create surplus labour beyond necessary labour". Decision makers hoped that "labourers may decide on the distribution of the fruits of labour at their own discretion, but such distribution must be responsible for society (Yu et al., 2008)". (quote from Kader) However, the fact was that the decision-making goals of workers' autonomous organisations were becoming increasingly short-term and personal income-eroded investments. As the motivation for accumulating "retained earnings" decreased, enterprises had to rely on loans for investment, and some enterprises even depended on loans to maximize workers' income (Schweickart, 2002) [3], which caused inevitable macro-economic problems. Although several reforms have been carried out, it is impossible to cure the root cause of underinvestment and low accumulation rate in the macro-economy. History proves that the accumulation of surplus labour also involves external coercion, considering the social nature of labour determined by productive forces.

At the initial stage of China's reform and opening up, some scholars in China always argued that "workers should be allowed to participate in the governance of SOEs according to the logic that "labour employs capital" (Li, 2005). However, the reform advanced cautiously towards the direction of a capital-oriented corporation. The reform of the modern enterprise system in the middle of 1990s defines the goal orientation of the reform to introduce the corporate system in the large and medium-sized SOEs. The corporate system is the leading form of the enterprise system in the modern market economy. It distributes the decisionmaking power according to capital authority and determines income distribution according to shareholding. The core of the power structure is capital sovereignty. With the phased implementation of the corporate system reform, the property rights system of large- and medium-sized SOEs in China transitioned from administrative ownership to capital-oriented ownership in terms of the legal framework. Later on, the downsizing-for-efficiency and reemployment programs starting from the latter half of the 1990s accelerated the adjustment of the contractual relationship between SOEs and the labourers. With the re-employment of tens of millions of laid-off labourers, the employment system of SOEs realised the transition from the national allocation system in a planned economy to a two-way selection and labour market allocation in a market economy. Thereby, the corporate system under the capitaloriented ownership was formed basically.

\section{Catching up miracle led by the public capital}

The market economy oriented by the public ownership in China generally adopts the corporate form under the capital-oriented ownership. Not only the non-public economy employs labour with capital, but also the state-owned economy that has great control over the national economy adopts the form of the corporation according to the logic of capital, which triggers much doubt and reproach. There is a popular notion that "a market economy with public ownership as the main form is a socialist economy". It is not a pure theoretical proposition but a practical issue. The achievements made by socialism with Chinese characteristics are the starting point for the understanding of the nature and significance of this statement. Facts have shown that the combination of the public capital's strong accumulation function and the improvement of people's welfare has dominated China's growth miracle that has lasted for more than 30 years. It is the primary basis for socialism with Chinese characteristics.

Since the reform and opening up, China's economy has been growing at an extraordinarily high rate, significantly reducing the economic gap between China and developed countries. 
By 2010, China's GDP exceeded 40 trillion yuans, making China the world's second-largest economy after the US. From 1978 to 2011, China's national GDP and GDP per capita grew at an annual average rate of $9.98 \%$ and $8.8 \%$, respectively. This achievement is unique in the process of industrialization in various countries (for country names, see the table below), thus triggering heated discussions on the causes of "China's miracle".

According to the methodology of the comparative public economy, the author needs to screen prosperous developmental states through the comparison and classification of global economies and analyse the common factors that affect their success. Then the author finds the uniqueness of China's model, explains the mechanism of its success and reveals the reasons for the success. It is not difficult to find that many economies made a quick start at the initial stage of their industrialization. However, there are not many countries that can continue to develop after reaching the middle-income level, and most of them are in East Asia. The characteristics of these economies can be summarized from three aspects.

First, the common characteristic of the fast-industrializing countries is state interventionoriented or even state-led industrialization. Large-scale investments at the early stage of industrialization require the state to mobilise and concentrate social resources on significant issues. The advancement of industrialization involves effective industry protection policies and successful national development strategies. National will and government capacity are critical drivers for successful industrialization, almost without exception for all developmental states in Latin America and East Asia. The centralized planned economy is only one of the particular forms of those economies and may also be the most radical one.

Second, the common characteristics of developmental states in East Asia are the East Asian-style social power structure and the cultural background of the Confucian tradition. The power structure is more open to a society with less stress on status hierarchy features, which helps to establish an economic system featuring inter-infiltration and long-term cooperation between the government and society. The Confucian culture traditionally emphasizes unity rather than struggle. With a high tendency for personal and household savings and considerable educational investments, the economies could concentrate more surplus labour and accumulate more human capital to achieve the rapid development of the social economy. Arrighi (2009) is right in commenting on the effect that China's economic strength is not abundant and cheap labour but the "high qualities of the labour force in health, education and self-management skills".

Third, China's uniqueness lies in the following fact: The country uses a gigantic public economy in its hand to lead extremely high capital accumulation and infrastructure investment. It also leverages its increasingly perfect market mechanism to mobilise the enthusiasm of various forms of ownership both home and abroad and thus realises an extraordinary growth of the economy. Compared with the past performance, the growth of China's economy in the last 30 years is significantly faster than that in the previous years, which can be explained by the market incentive effect of the reform and opening up. Compared with the other economies in the world, including the successful developmental states in East Asia, among the set of the causes of high growth, the most critical factor that cannot be ignored is adherence to public ownership as the mainstay. Unlike a private capital, a state-owned capital is capital without capitalist. Therefore, a state-owned capital is free of the conflict between the accumulation of private capital and consumption (Marx, 1975), and the social nature of a state-owned capital determines its higher tendency to accumulate capital. Compared with a private capital, a public capital enjoys a longer-term investment horizon. As a public capital represents labourers' long-term interest more than their immediate interest, it is more willing to accept investment projects with a larger scale and a longer payback period. These two points can adequately explain the remarkable mobilisation capability of China's governments during state industrialization. Since the reform and opening up, China has successfully promoted the development of the private economy by
Productivity, public capital and socialism 
CPE 3,1

combing the public ownership with the market economy and letting some people get rich first. Also, China spurs the development of joint ventures and wholly foreign-owned enterprises by combining domestic market and international market as well as attracting investment. In the meantime, the state-owned economy gradually consolidates the form of the state-owned capital, thus enhancing the latter's accumulation tendency and competitiveness. Finally, the development of the mixed-ownership economy attracts an increasing social capital to participate in China's economic construction. The reform of socialist market economy realises Chairman Mao's aspiration 60 years ago: "In short, we should mobilise all positive forces, whether within or outside the Party or the country, or whether direct or indirect, to make China a powerful socialist country" (Mao, 1999). Practices show that without the market mechanism, it is impossible to mobilise economic resources entirely with the only reliance on national enthusiasm.

To sum up, the success of contemporary China's catch-up strategy is attributed to the combination of public ownership and market economy, and the public capital dominates the course of China's reform and development. This experience has been recorded in the annals of history and becomes the treasure of humans, especially people in developing countries.

However, there is a notion that realistic socialism "narrows the gap at any cost" and conflicts with the goal of socialism construction (i.e., elimination of alienated labour) and that such achievement is not worth mentioning. This seemingly orthodox idea neglects two the major practical perspectives as follows.

The first one is the perspective of people's lives. During the catch-up period (1979-2011), China's total consumption grew at an annual average rate of $9.2 \%$, slightly lower than the average growth rate of GDP at that time, which was $9.8 \%$. Almost every Chinese family can tell a true story about how the lives of Chinese people have changed during the rapid growth of more than 30 years. Although the inequality of distribution increases somewhat, it is an indisputable fact that the lives of the people at the bottom of society have improved. According to Annual Report on Poverty Reduction of China 2016 (Zhongguo fupin kaifa baogao 2016) jointly released by Chinese Academy of Social Sciences (CASS) and the State Council Leading Group Office of Poverty Alleviation and Development, based on the World Bank's poverty standard of 1.9 US dollars per day in terms of purchasing power parity (PPP) in 2011, the reduction in the number of impoverished people all over the world between 1981 and 2012 was $1.1 \mathrm{bn}$. The reduction in the number of impoverished people in China was $790 \mathrm{~m}$, occupying $71.82 \%$ of the global total (The Economic Daily, 2016). For China, which used to be one of the world's poorest big developing countries, is this feat not worth mentioning? Lancaster (1973) establishes the optimal social model of capital accumulation based on gaming between workers and capitalists. This model proves that with total social consumption as the social welfare index, the optimal social path of economic growth before a specific time point $t^{*}$ is the path to maintain maximum accumulation. Assuming that the economic gains are shared between labour and capital in a given means, this path is conducive to the overall, long-term interest of labourers. China's catch-up strategy marked by high accumulation and high economic growth can be deemed a living proof of the Lancaster model.

The second one is the perspective of the global economy. The polarisation of global economies tends to intensify. According to the dependency theory of Frank (1999) and Dos Santos (1999), due to the competitive coercion of global market and the control and exploitation by core countries, peripheral countries (i.e., a vast number of developing countries) are faced with a dilemma of how to get out of the dependency. It seems there is no way out. The later theory of "dependent development" argues that even if a few peripheral countries could prosper, their development is dependent, which cannot change the economic pattern of polarisation dominated by international capital. The rise of China's economy is stiff resistance to global capitalism, not only because the rapid improvement of the living 
conditions of 1.3 bn people offset the trend of polarisation greatly but also because China, a big developing country that used to be one of the poorest countries in the world, realised the transformation to a middle-income country within a few decades. China's experience of supernormal development has already attracted the attention of developing countries around the world and will produce a more significant impact in the future. China has not only succeeded in drastically reducing the number of the poverty-stricken population but also has the ability and experience to assist other developing countries to fulfil their goals of poverty reduction (Xinhuanet, 2014) [4]. The market economy with public ownership as the mainstay is the flag of China's model, and the growth miracle led by the public capital has raised the hopes of a vast number of developing countries. The impact of China's model on global capitalist order and its inspiration for global socialism cannot and should not be overlooked by contemporary Marxism.

\section{Break free of capitalist obstacles to productivity}

Socialism is a process of continually breaking through institutional obstacles and promoting social productivity. In this process, socialism with Chinese characteristics leverages the public capital's innovative impetus and immunity to the capitalist crisis to break through capitalist obstacles and develop productivity continually. It has demonstrated and will continue to demonstrate the historical legitimacy of socialism.

The basic conclusion of the Marxist political economy is that capitalism has impeded the development of social productivity due to the fundamental capitalist conflicts and must be replaced by a new social system to promote the progress of the human society continuously. The Marxist political economy analysis of capitalism focusses on the following two points: (1) The accumulation of private capital inevitably results in relative surplus population and the polarisation of wealth and poverty, which will not only cause social conflicts but also bring about a severe problem on fulfilment of the reproduction of social capital. As a result, periodic crises are inevitable. (2) Profit-oriented capitalist production has a long-term trend of the declining general profit rate, resulting in the depletion of the motive power of social production, which is a deeper cause of the economic crisis. A bourgeois society has to control the increase of the surplus-value rate for overcoming the first conflict. However, to prevent the second conflict, improving the rate of exploitation or rate of surplus rate is the most effective method for capitalists to deal with the pressure of competition. No matter what it chooses to do, this society could not find a way out but has to go to its doom during selfconflicts.

The unprecedented crisis of the capitalist world in the first half of the 20th century and the two world wars before and after that crisis are definite proof of the Marxist economic theory. The catastrophe triggered by the intrinsic contradictions of the capitalist economy now remains a miserable memory for all people. After World War II, the capitalist economy experienced a golden age of economic growth for nearly 30 years. From 1950 to 1975, the GDP of developed countries grew at an unprecedented annual average rate of $4 \%$ or more. Some people attempt to prove that the capitalist system can repair itself and that the fundamental contradiction identified by Marx has been overcome. Typically, based on the data of the above period, Kuznets put forward the inverted U curve showing the relationship between economic growth and social inequality and argued that capitalism had made self-correction on its characteristic polarizing trend. There is a growing body of research showing that the existence of the so-called golden era of economic growth does not negate but validate Marx's conclusion. It was the crises and wars that destroyed "backward capacities" in great numbers and pricked over-expanding asset bubbles. Those crises and wars "bridged the income gap" and removed the garbage of conflicts of capitalism accumulated over a long time through the large-scale destruction of wealth. It was the prerequisite for the golden period of economic growth after the World War II. After the 1970s, the golden time ended with the emergence of
Productivity, public capital and socialism 
CPE 3,1 the oil crisis, and accumulated conflicts resurfaced. In his book Capital in the Twenty-First Century, Piketty (2014) applied massive amounts of data to prove the long-term trends of the capitalist economy again. The so-called "inverted U curve" is a temporary exception created by the crises and wars, and the capitalist polarisation trend has never changed. Therefore, humans cannot help asking themselves the question: "Is it necessary to maintain such a social system? If short-term prosperity is achieved at the cost of great disasters and the lives of hundreds of millions of people, are we willing to bear such cost? Should our offspring bear such cost?"

Socialist revolution is a definite answer to this centurial question, and the Russian communist party took the lead in shouldering this historical responsibility. According to the classic theory, the social productivity should be prepared in advance. Once advanced productive relations are established, the productivity unleashed from the shackles of capitalism will increase naturally. Unexpectedly, revolutions usually break out in an economically backward country. At first, the Russian communists did not believe they could build socialism alone, and they struggled hard for the support from successful revolutions in advanced countries. The "socialism in one country" is entirely the product of the grave situation and is faced with two major problems from the very beginning, as follows: First, how to get out of the situation of being in a passive position and taking a beating in international competition (not only in economic but also in political and even military competitions). Second, how to improve the living standards of the people. There is only one solution to these two problems: to develop productive forces faster.

In fact, the economy of the Soviet Union used to develop satisfactorily. In 1927-1975, the GDP of the Soviet Union grew at an annual average rate of 4.5\%, outperforming the United States. Within 48 years, the Soviet Union's GDP grew eight times. In contrast, the US's GDP grew merely over four times. According to an estimate, by 1975, the Soviet Union's GDP was roughly $60 \%$ of the US's GDP, thus significantly narrowing the gap between these two powers by economic aggregate (Kotz et al., 2010). In particular, against the background of the great crisis of the Western world in the 1930s, the Soviet Union's economy still thrived, which fully demonstrated the strong resistance of the public ownership economy to the crisis. However, after WWII, the capitalist world experienced a golden era of economic growth, and the gap between the US and the Soviet Union by growth rate contracted gradually. After the middle of the 1970s, the Soviet Union's economy suddenly stagnated, and the US overtook the Soviet Union in terms of the economic growth rate. Although the reasons have been discussed repeatedly, there is no convincing answer (Kotz et al., 2010). In the author's opinion, this may well be related to the economic system and the shift in dynamic source for economic growth. The developing economies usually have to go through a shift of the primary driver for growth from investment to innovation sooner or later. The economy of the Soviet Union lingered at the crossroads for long and failed to overpass it. The root cause of it is that the centralized planned economic system has neither a flexible resource allocation nor an effective incentive for innovation. With a clumsy economic system operation and practice of copying old management methods, the old drivers for growth were exhausted gradually, and new growth drivers failed to be formed. The external impact of the oil crisis in 1973 highlighted accumulated conflicts, and a stalling economy became the trigger for the collapse of the Soviet system. Practice proves that maintaining the continuous development of productive forces is always a vital matter for socialist practice.

In the 1970s, China also faced economic plight. On the one hand, the domestic economy suffered setbacks during the two aggressive experiments, including the people's commune and Cultural Revolution, and economic growth was not satisfactory. On the other hand, the rapid development of Japan's economy after the WWII and the rise of "Four Asian Tigers" exerted external pressure on China's economy. The difference between China and the Soviet Union is that China's GDP per capita was merely 839 international dollars in 1973, which was 
one-seventh of the Soviet Union's GDP per capita within the same period (Maddison, 2003). China faced the demands for reform at a relatively low level of economic growth, and the issue on the transition from the old to new drivers of growth did not appear yet. Hence, the reform of China was relatively unhurried. The objective of China's reform was to promote the economic development with the market mechanism, while the goal of opening up is to accelerate China's economic development in the international competition. These were drawn from the successful experience of other countries. However, China also sticks to its path, rejecting dependent development and adhering to the basic economic system with public ownership as the main form. The state-owned economy exits from the fields of small-scale production and operation, thus making room for the development of small- and medium-sized private capital. The public capital is encouraged to develop aggressively in large-scale production and operation fields, which are more suitable for giving full play to its advantages. It increases its scale and power through the competition with domestic and international large-amount capital. The practice has proven that the basic economic system, with public ownership as the main form and mutual development of various economic sectors, is correct. The reform not only unleashed the initiative of various domestic economic forces but also started the transition from an outward expanded reproduction to an inward expanded reproduction by introducing foreign capital as well as learning and assimilating foreign advanced technologies and management approaches.

However, a high accumulation and high investment remain the primary driver of growth. Within more than 30 years of the reform and opening up, China's investment ratio (i.e., the ratio of gross capital formation to GDP) always remain at a high level of $30 \%-40 \%$, and the figure reached or exceeded $40 \%$ within recent ten years. The drivers of growth will change sooner or later as outward expansion can no longer support the substantial investment increment, and the growth based on introduced technology presupposes a relatively big technical gap (i.e., socalled late-mover advantage). In those years, the gap in the total GDP between the Soviet Union and the United States contracted to approximately $60 \%$, and the Soviet Union's late-mover advantage began to weaken. Nowadays, the gap in the total GDP between China and the US hovers at this level, and the issue of growth driver transition arises as expected. China has used its trade surplus with the US to absorb a portion of domestic capacities for a period. After the financial crisis in 2008, China has to put the transformation of the economic development pattern on the agenda due to shrinking foreign trade. The "new normal" of China's economy is a concept with extremely rich connotations, and its core is the shift in the growth rate and the transformation of power. In other words, the economic growth transitions from the "old normal" reliant on high accumulation and high investment to the "new normal" that relies less on accumulation rate and more on innovation-driven. As the change of the inertia resulting from the high accumulation over dozens of years has impacts on the whole situation of reproduction and involves a series of demand-side and supply-side structural adjustments, the transition must be complicated, arduous and somewhat time-consuming.

China's economy arrives at a crossroads again. Breaking through the institutional obstacles of developing productive forces is the only way out. China has the following foundations for success: First, the present situation of China is different from the former Soviet Union's circumstances at that time. China is already on the right track of the socialist market economy, and a further deepening reform is a matter of course. China need not act in haste or choose a development path without deliberation. New growth drivers call for a stronger innovation incentive. The market competition where capital pursues excess surplus value is the most potent innovation incentive mechanism that we have ever discovered - it not only rewards enterprise innovation with large amounts of excess surplus value but also compels enterprises to make sustained innovation by diffusion of innovation and loss of rewards through market competition. Marx's discussion on relative surplus-value production (Marx, 1975) lays a foundation for economic innovation theory. It also provides a theoretical basis for
Productivity, public capital and socialism 
CPE 3,1

136

our present effort to improve further the innovation incentive mechanism in a socialist market economy. Further deepening the reform of the state-owned economy based on the capital's logic is a crucial step to improve innovation incentive. A mechanism encouraging mass entrepreneurship and innovation will be improved gradually on such basis.

Second, unlike the global capitalist economy, China's market economy is dominated by the public capital with the public ownership playing the dominant role. In the face of the sudden but lingering global economic crisis, China's economy has stronger immunity. Hence, China is expected to take the lead in getting over the ongoing downturn and bringing the global economy a new impetus. On the one hand, as public capital is capital without capitalist and property rights belong to all the people, public capital is intrinsically conducive to labour democracy and distributive justice. The accumulation law of public capital is not a polarisation of wealth and poverty but a positive factor that may be brought into full play during the ongoing reform to bridge the income distribution gap - for instance, deepen the reform of the distribution system within the SOEs, improve the profit-delivering system of SOEs and replenish social security funds with the state-owned capital. When the state-owned capital maintains a relatively large proportion, it has a positive effect on distributive justice in the whole society, for it reduces the property shares of billionaires, which helps ensure the overall justice of social distribution. On the other hand, despite the long-term trend that the profit margin will decline in the market economy, the public capital maintains a robust growth momentum. Compared with the private capital, the public capital pays more attention to the labourers' overall interest and long-term interest. It sets the improvement of the people's material and cultural life as a long-term goal during coordination between accumulation and consumption. Therefore, during competition with private capital, public capital will have much stronger tolerance and adaptability to declining profit margins. This feature will translate into more robust competitiveness over time. Unlike most economists, the author believes that in a more rounded market environment and a higher degree of economic development, the mature public capital will have stronger strengths and a higher proportion.

In summary, in terms of basic system, there is sufficient reason to believe that China's economy will smoothly realise the transformation of the development pattern and take the lead in weathering through the global crisis. This must be good news for global economic recovery.

It is not difficult to predict this prospect, and it is more important to understand the significance of such a prospect. Some say that China's success will rescue global capitalism. Well, how will China do the rescue? - through a Marxist ruling party, a basic economic system with public ownership playing the dominant role, development pace surpassing that of global capitalism and an economic performance that takes most of the poor to a moderately

Table 1.

Comparison of the average GDP growth of countries during their industrialization stages. Quoted from Shi (2013)

\begin{tabular}{llccc}
\hline Country & Development stage & Time & Annual GDP growth (\%) & GDP per capita growth (\%) \\
\hline UK & Frontier country & $1820-1870$ & 2.05 & 1.26 \\
US & Follower-frontier country & $1870-1913$ & 4.04 & 1.82 \\
Japan (1) & Catching-up country & $1950-1973$ & 8.92 & 7.70 \\
Japan (2) & Catching-up country & $1950-1984$ & 7.20 & 6.09 \\
India & Catching-up country & $1990-2011$ & 6.47 & 4.66 \\
China & Catching-up country & $1978-2011$ & 9.98 & 8.80
\end{tabular}

Source(s): Data about the UK and US are derived from The World Economy: A Millennial Perspective written by Angus Maddison and translated by Wu Xiaoying et al., Peking University Press (2003). Data about Japan are from "Historical Statistics of Japan-Gross Domestic Product Classified by Economic Activities-685SNA" by Statistics Japan with the 1990 figures as the base. Data about India are from "World Economic and Financial Surveys" by IMF in October 2012. Data about China are from China Statistical Yearbook 2012 compiled by the National Bureau of Statistics of China, China Statistics Press (2012) 
well-off society in all aspects. Chinese people have the "life expectancy" and "average length of schooling" surpassing their economic development levels, quickly rising wage level and gradually narrowing urban-rural gaps. If the observers are willing to do some dynamic analysis, it is not hard for them to find that China's path is fundamentally different from any capitalist development path in the world. China's current market economy, which follows the capital's logic, retains so many characteristics different from those of a capitalist market economy that any economist feels somewhat hesitant before calling China's market economy the capitalist economy. According to Giovanni Arrighi (2009), "Look at today's China, and some people may say this may be or may not be capitalism-I think this is a question worth discussing. Even if it is supposed to be capitalism, it is entirely different from any historical capitalism. It is a radically changed capitalism.” Arrighi's comment is thought-provoking. As China's economy is "entirely different from any historical capitalism" and is a "radically changed capitalism", why do some people still call it capitalism? Is that because it fails to break through the shackles of capitalism to develop social productivity faster? Is that because it fails to take the people to a comprehensive well-off society within a shorter period? Or is that because this kind of development does not rely on the nation's strengths but relies on robbery and exploitation of the other developing countries? None of them makes sense. The root cause is the traditional socialist doctrine. Socialism with Chinese characteristics is different from all previous theories. It is the fruit of the long-term socialist practice under the guidance of the classical theories and contains many modifications in theories attributed to practical experience. China's socialism is a market economy governed by a Marxist ruling party with public ownership playing the dominant role. Such socialism can break through the shackles of capitalism on social productivity and realise common prosperity and maximization of the people's long-term interests. If China can "rescue capitalism" in this way, it proves that the socialist system is superior to capitalism. Francis Fukuyama once said that "China and the West are engaged in a historical competition of development models" (Fukuyama, 2016), of which the result will determine the prospects of the vast majority of European and Asian countries and regions in the coming several decades. It seems that socialism with Chinese characteristics suffices to prove that its history is still far from the end.

\section{Notes}

1. "Although the 'post-capitalist society' transcends capitalism, it fails to transcend capital. This 'organic system' that alienates the rule over labour will inevitably return to capitalism."

2. According to Henry Levin, "All workers-managed companies may be possibly more efficient than their capitalist counterparts."

3. "Compared with capitalist companies, workers-managed enterprises have a much weaker internal driver for expanded production. The competitive instinct of self-managed enterprises is more defensive than offensive."

4. According to the speech by Ajay Chhibber, assistant secretary-general of the United Nations, at the news conference of the headquarters of the Asian Development Bank on February 17, 2010.

\section{References}

Alchian, A. and Demsetz, H. (1994), "Shengchan xinxi chengben he jingji zuzhi [production, information costs and economic organisation]", in Shouying, L. et al. (Trans.), Caichan quanli yu zhidu bianqian: chanquan xuepai yu xinzhidu xuepai yiwenji [Property Rights and Institutional Changes: A Collection of Translated Essays in Property-Right Economics and Neo-Institutional School], Shanghai Sanlian Press and Shanghai People's Publishing House, Shanghai.

Amin, S. (2003), Ziben zhuyi de weiji [The Crisis of Capitalism] (Chinese Edition), Social Sciences Academic Press, Beijing.
Productivity, public capital and socialism 
CPE 3,1

Arrighi, G. (2009), Yadangsimi zai Beijing: 21 shiji de puxi [Adam Smith in Beijing: Lineages of the Twenty-First Century], Social Sciences Academic Press, Beijing.

Dos Santos, T. (1999), Diguo zhuyi yu yifu [Imperialism and Dependence] (Chinese Edition), Social Sciences Academic Press, Beijing.

Frank, A.G. (1999), Yifuxing jilei yu bufada [Dependent Accumulation and Underdevelopment] (Chinese Edition), Yilin Press, Nanjing.

Fukuyama, F. (2016), "China and the West are engaged in a historical competition of development models", available at: http://www.thepaper.cn/newsDetail_forward_1427248 (accessed 29 January 2016).

Gordon, D.M., Richard, E. and Michael, R. (1982), Segmented Work, Divided Labourers, Cambridge University Press, Cambridge.

Gu, H.L. (Ed.) (2014), Bainian zhenglun: 20 shiji xifang xuezhe makesi jingjixue yanjiu shuyao (Zhongce) [Debates in One Hundred Years: Summary of Marxist Economic Research by Western Scholars in the $20^{\text {th }}$ Century (II)], Economic Science Press, Beijing, p. 973.

Kotz, D. et al. (2010), Laizi shangceng de geming: sulian tizhi de zhongjie [Revolution from Above: The Demise of the Soviet System] (Chinese Edition), China Renmin University Press, Beijing.

Lancaster, K. (1973), “The dynamic inefficiency of capitalism”, Journal of Political Economy, Vol. 81 No. 5, pp. 1092-1109.

Li, B.Y. (2005), Zhongguo qigai xintan [New Discussions on Enterprise Reform in China], Democracy and Construction Publishing House, Beijing.

Maddison, A. (2003), Shijie jingji qiannianshi [The World Economy: A Millennial Perspective], Peking University Press, Beijing.

Maddison, A. (2008), Zhongguo jingji de changqi biaoxian: gongyuan 960-2030 nian [China's Economic Performance in the Long Run: 960-2030 AD], Shanghai People's Publishing House, Shanghai.

Mao, Z.D. (1999), "Lun shida guanxi [On the ten major relationships]", in Party Literature Research Center of the CPC Central Committee (Ed.), Mao Zedong xuanji [The Selected Works of Mao Zedong], Vol. 7, People's Publishing House, Beijing, p. 44.

Marx, K. and Engels, F. (1979), Makesi engesi quanji [The Collected Works of Karl Marx and Frederick Engels] (Chinese Edition), Book 1 of Vol. 46, People's Publishing House, Beijing, pp. 108-287.

Marx, K. and Engels, F. (1980), Makesi engesi quanji [The Collected Works of Karl Marx and Frederick Engels] (Chinese Edition), Book 2 of Vol. 46, People's Publishing House, Beijing, pp. 113-225.

Marx, K. (1975), Zibenlun [Capital] (Chinese edition), Vol. 1, People's Publishing House, Beijing, pp. 351-651.

Mèszaros, I. (2003), Chaoyue ziben: guanyu yizhong guodu lilun [Beyond Capital: Towards a Theory of Transition, Chinese Ed., China Renmin University Press, Beijing, p. 739.

Piketty, T. (2014), ziben lun [Capital in the Twenty-First Century] (Chinese Edition), CITIC Press, Beijing, p. 21.

Rong, Z.Z. et al. (2010), Laodong pingdeng lun: wanshan shehui zhuyi jingji zhidu yanjiu [On Labour Equality: A Study of Improving the Basic Socialist Economic System], Social Sciences Academic Press, Beijing.

Rong, Z.Z. (1996), "Lun gongyou chanquan de neizai maodun [On the Inner Contradictions of Public Ownership]", Jingji yanjiu [Economic Research Journal], Vol. 42 No. 9, p. 1623.

Rong, Z.Z. (2000), "Jingjixue de xiquexing yu makesi de shehui lilun [Scarcity in Economics and Prosperous Society in Marxist Theory]", Jiaoxue yu yanjiu [Teaching and Research], Vol. 39 No. 4, pp. 21-25.

Schweickart, D. (2002), Fandui zibenzhuyi [Against Capitalism] (Chinese Edition), China Renmin University Press, Beijing, pp. 99-104. 
Shi, Z.F. (2013), Chaochang zengzhang: 1979-2049 nian de zhongguo jingji [Supernormal Growth: China's Economy in 1979-2049], Shanghai People's Publishing House, Shanghai.

The Economic Daily (2016), “China's poverty reduction contributes greatly to the world, its reduction of the poor population represents over $70 \%$ of the global total", available at: http://www.gov.cn/ xinwen/2016-12/28/content_5153660.htm (accessed 28 December 2016).

Xinhuanet (2014), "China makes contribution to global poverty reduction", available at: http://news. xinhuanet.com/politics/2014-10/11/c_127086679.htm (accessed 11 October 2014).

Yu, W.L. et al. (2008), Shichang shehui zhuyi: lishi litun yu moshi [Market Socialism: History, Theories and Models], Economic Daily Press, Beijing, pp. 134-135.

\section{About the author}

Zhaozi Rong, professor of Anhui University and the executive dean of the Institute for Advanced Study of Economic and Social Development, Anhui University. Zhaozi Rong can be contacted at: rongzhzi@ sina.com
Productivity, public capital and socialism

For instructions on how to order reprints of this article, please visit our website: 